\title{
DA ORDEM. DA CIDADE. DA LITERATURA: personagens à beira do "ruim do mundo"
}

Eliana Kuster*

Robert Moses Pechman**

\begin{abstract}
Resumo: As grandes cidades estão doentes. Seus sintomas: a quebra da sociabilidade e a irrupção rotineira da violência. Diante disso, ecoa na sociedade um clamor por ordem. No mesmo momento em que a polícia põe a tropa na rua, os literatos criam personagens que dão voz à sensação crescente de que a cidade está deixando de ser uma referência à constituição das identidades urbanas. É a partir da literatura, em especial da obra do escritor Rubem Fonseca, que iremos perscrutar as possibilidades apresentadas pela cidade para $\mathrm{o}$ convívio humano.
\end{abstract}

Palavras-chave: cidade, cidadania, ordem, literatura, Rubem Fonseca.

\section{Introdução}

Rubem Fonseca é daqueles autores que acreditam que a literatura é capaz de, se não transformar o mundo, pelo menos, criar novos mundos. Rubem Fonseca é um literato que lê literatura. Além de fazer literatura, Fonseca usa a literatura como contraponto para... fazer literatura. É por isso que é inevitável transitar pela literatura e por literatos para compreender o universo desse autor, cuja obra é

\footnotetext{
* Arquiteta, professora do Centro Federal de Educação Tecnológica do Espírito Santo (CEFET/ES) e doutoranda no Instituto de Pesquisa e Planejamento Urbano e Regional Instituto de Pesquisa e Planejamento Urbano e Regional (IPPUR) da Universidade Federal do Rio de Janeiro (UFRJ).

${ }^{* *}$ Historiador e professor do IPPUR/UFRJ.
}

Artigo recebido em 8 nov. 2007 e aprovado em 28 nov. 2007. 
fortemente marcada pelo diálogo com outras obras e que, no caso de Fonseca, remete para o drama da vida e dos acontecimentos urbanos. $\mathrm{E}$, arriscamos dizer, que se quisermos compreender, a partir de seu universo, algo da alma urbana de seus personagens, poderíamos nos deter sobre as epígrafes com que o escritor abre seus livros de contos. Nelas, podemos pressentir um certo devir que anuncia o movimento principal do autor: o arrancar de seus personagens do lugar da intimidade familiar e o seu lançamento na amplidão do mundo.

A propósito da questão do ethos de seus personagens e como, a partir daí, eles se lançam na aventura urbana experimentando a convivialidade e seus impactos na estruturação de uma urbanidade, tomemos essas epígrafes. A partir daí, poderemos verificar como Fonseca desenhou um percurso capaz de nos revelar o seu movimento interno. A sua escrita se desloca, a cada livro, rumo à constituição de uma temática cujo fio condutor é o frágil equilíbrio entre a subjetividade e a objetividade das relações sociais, entre a casa e a rua, entre o privado e o público. Ou melhor, um percurso que, quanto mais urbano for, mais estará indagando dos personagens algo de sua subjetividade. Nesse sentido, vamos tomar, na seqüência temporal com que os livros foram publicados, as epígrafes dos livros: Os prisioneiros (1963), A coleira do cão (1965), Lúcia McCartney (1969), Feliz ano novo (1975), O cobrador (1979), Histórias de amor (1997) e Pequenas criaturas (2002).

Pontuando uma espécie de trajetória, essas epígrafes nos servem para tematizar a própria urbanidade, uma vez que elas revelam o processo de constituição de um "sujeito urbano" que sai do aconchego do lar e se lança no vazio da cidade impessoal. Assim, se tomarmos a epígrafe do primeiro livro Os prisioneiros ("Somos prisioneiros de nós mesmos. Nunca se esqueça disso, e de que não há fuga possivel"), e compararmos com a que lhe segue, do livro A coleira do cão ("Já quebrei meus grilhões, dirás talvez. 
Também o cão, com grande esforço, arranca-se da cadeia e foge. Mas, preso à coleira, vai arrastando um bom pedaço da corrente”), vemos claramente o ponto de partida de uma trajetória, na qual os personagens, que inicialmente eram prisioneiros de si mesmos, rompem seus grilhões e lançam-se ao mundo, mas carregando ainda o travo de sua vida familiar, um pedaço de corrente que lhes tolhe os movimentos.

Seguimos em frente, e vamos encontrar Lúcia McCartney, onde a epígrafe, retirada do livro do Apocalipse, nos fala em morte e destruição: “... E apareceu um cavalo amarelo: e o que estava montado sobre ele tinha por nome Morte, e seguia-o o Inferno...". Quem se arrisca à vida pública, sugere Fonseca, é passível de se deparar com o inesperado, que pode tomar a forma da desgraça - a morte - e da escassez - a fome. Tal escassez, o autor irá retomar na epígrafe do livro seguinte, Feliz ano novo, através de um poema francês do século XVIII, que determina que: “...na escassez não espere grande lealdade...”. Não satisfeito com esse indício, Fonseca reafirma, no mesmo livro, que “...os anos que passam arrebatam os nossos bens um a um...”. Para Fonseca, a cidade parece ser um vórtice, seduzindo e capturando os homens, ao mesmo tempo em que os lança à própria sorte. $\mathrm{O}$ patético de tal trajetória é digno de piedade, ou talvez, de escárnio, coisa que o autor nos mostra em O cobrador, cuja epígrafe declama: “... Sorride, ridiculai, risando, risantes, / Hilariando, riando / Ride, ridentes!...”.

Por fim, temos as epígrafes dos livros Histórias de amor e Pequenas criaturas. Na primeira, Fonseca ameaça com a volta para o universo privado, representado pelos afetos: "Há o amor, é claro. E há a vida, sua inimiga". Apesar de reconhecer a inevitabilidade do amor, o autor adverte que este será anulado pela vida, deixando claro o fato de que um se opõe ao outro. Diante deste panorama, o universo que cabe aos homens reduz-se inexoravelmente. $\mathrm{O}$ autor reconhece tal evidência, e lhe dá voz, no livro Pequenas criaturas. 
Ali, espremido entre o amor e a vida, Fonseca se detém sobre o minúsculo da sobrevivência, sobre a vida em seu mínimo, preparando o leitor para a sucessão de contos que tematizam este dilema no cotidiano das pequenas criaturas urbanas com a epígrafe: “... $E$ mediante o estudo das pequenas coisas que alcançamos a grande arte de termos um mínimo de desgraça e o máximo de felicidade possiveis". A pequenez dos personagens é, para Fonseca, a sua única chance de sobrevivência... na cidade.

\section{Cidade ou cidadela?}

Cada vez que abrimos o jornal, enquanto sorvemos o café fumegando, e nos deparamos com algumas daquelas violências que tornam nossas cidades manchetes de jornal no mundo inteiro, nos sentimos baquear. A indignação nos invade e trovejamos: ordem! Precisamos de ordem. A cidade precisa de ordem. Chamem a polícia!

O apelo à ordem - e que esta seja de natureza policial e não da estirpe da cidadania - é sintomático de como estamos pensando nossas cidades e, evidentemente, a sociabilidade que lhes dá vida. $\mathrm{O}$ nosso mal-estar urbano está levando ao que alguns autores já estão chamando de uma "era da segurança", o que em termos da vida urbana contemporânea nos empurra a ter que optar entre a cidade aberta ou a cidadela fechada.

A associação imediata da palavra "ordem" ao aparato policial e não a uma nova ordenação da convivialidade a partir da atualização do pacto urbano se explica. Se formos consultar o significado desse termo no dicionário, constataremos que "ordem" tem uma enorme lista de significados, dentre os quais, podemos ressaltar: "regra ou lei estabelecida; tranqüilidade pública resultante da conformidade às leis" ou, ainda, "disciplina, subordinação; determinação de autoridade, mandado, prescrição, ordenação" (Ferreira, 1995, p. 468). 
Significados ligados, portanto, ao respeito das leis e - caso este não exista naturalmente, através de comportamentos mutuamente pactuados -, à sua imposição através da autoridade: do governo, dos cidadãos, das instituições... da polícia.

Da ordem desejada, ou seja, daquela que nos acena com a possibilidade de um convívio sem grandes sobressaltos de violência, parece que estamos transitando para uma ordem da subordinação, esta estritamente policial, com todas as conseqüências disso para as cidades que começam a experimentar as dores e horrores de se transformar em cidadelas. Isso, sem nos darmos conta que os conceitos de ordem são diferentes, na medida em que um remete para um convívio pactuado e outro passa às mãos da polícia o "governo" da cidade. Quando falha o pacto entra a sujeição, e é mais do que natural o nosso anseio diante das notícias de jornal - a cada edição que clama e reclama por ordem - em associá-la a uma ordem policial que organize e pacifique a cidade.

Mas será que a cidade precisa desse tipo de ordem policial? Quem almeja essa ordem é a cidadela, que é fortificada, que é uma máquina de guerra. Nesse sentido as cidades medievais, que não conheciam o pacto, apelavam para uma ordem contida na fortificação. Muradas, controladas, vigiadas por sentinelas, aquelas cidadelas muitas vezes nos parecem, hoje, um modelo a retomar, perante o imaginário de que vivemos num caos urbano.

Porém, aqui cabe a diferenciação entre o que é cidade - enquanto lugar da confraternização cidadã, espaço público de coexistência - e o que é a cidadela, ponto de defesa no espaço e que serve à proteção da vida e, fundamentalmente, das riquezas que se escondem entre seus muros, portanto, um espaço sempre pronto a se defender. Quando preparada para atacar ou se defender do outro, a cidade deixa de ser cidade e se transforma numa espécie de acampamento militar (Portella, 1995), onde não cabem mais os 
fundamentos sobre os quais a cidade - como pólis - foi fundada: a Hospitalidade e a Amizade. ${ }^{1}$

Se alguma disciplina devemos impor à cidade, que esta seja a disciplina da solidariedade, a norma da convivialidade. De fato, as cidades, alerta Eduardo Portella (1995, p.110), estão extenuadas de tanta desordem e violência, mas não é a ordem policial, muito menos a violência que esta ordem impõe, que hão de fazer a cidade voltar à sua condição de lugar de compartilhamento da existência, lugar de coabitação cidadã. $\mathrm{O}$ que a cidade carece não é mais ordem, mas de investimento afetivo. É preciso equilibrar, insiste Portella, as relações de produção com a produção de relações (p. 109). Essa mesma cidade que busca ordenar seus componentes para uma maior otimização de seus fluxos funcionais e econômicos, tem desprezado seus fluxos relacionais. Ou seja, que tipo de relação entre os seus a cidade moderna está propiciando?

O próprio planejamento urbano, que é um sistema de racionalizar o espaço da cidade, de ordenar os seus elementos, acaba servindo também como um dos instrumentos de imposição de uma determinada visão sobre o urbano que insiste em privilegiar as coisas e negligenciar as pessoas (Portella, 1995, p.112).

Planejamento! Clamam os urbanistas. Lei! Proclamam os juristas. Ordem pública! Berra a polícia. Paz! Clamam os cidadãos.

Não estamos propondo que se combata as AR 15 e granadas dos traficantes com flores, nem tampouco que a violência seja barrada pelas gentilezas da Hospitalidade e as alegrias da Amizade. Reconhecemos que vivemos um momento dramático de nossa existência como citadinos e cidadãos. A perspectiva de que basta sair à rua para estarmos em risco, ou, de que mesmo resguardados em casa, possamos passar à condição de vítimas, é intolerável. Diante disso, a questão da ordem e do policiamento na cidade se recoloca. 
Não nos espanta que a reação à violência se dê única e exclusivamente a partir da idéia de proteção: da vida e do patrimônio. É elementar que todos queiram se sentir protegidos em sua cidade. Mas para além da idéia da ordem que é imposta para conter a desordem, o que chama a atenção é como o tema de uma "ordem policial" é manipulado como o antídoto para conter a desordem urbana, afastando a possibilidade de compreensão da violência urbana pela perspectiva de uma ordem pública, construída na convivialidade e na "vigilância" cidadã. Em suma, a discussão da ordem na cidade esconde, esvazia mesmo, a dimensão política da experiência da vida coletiva na urbe.

Se tomarmos como princípio que o fundamento da vida em cidade é a coabitação cidadã, ${ }^{2}$ concluiremos que os termos civilidade e civil são termos que, pela sua etimologia, revelam práticas sociais onde a coabitação e o convívio entre os diferentes dariam sentido à cidade como lugar efetivo da urbanidade e do processo civilizador.

Seria interessante, portanto, tentar recuperar o momento em que, na cidade, a vida pública começa a dar sinais de não sustentar mais a legitimidade que emprestava à experiência de uma sociabilidade urbana. Ou seja, aquele momento em que a cidade se "despolitiza" como lugar doador de sentido à constituição de um imaginário urbano sobre as formas da convivialidade, para se tornar o lugar da familialização do privado. ${ }^{3}$

Segundo Francisco Ortega (2002, p. 15), isso teria acontecido no momento em que as redes de sociabilidade e convivialidade que ligavam os indivíduos entre si, ou seja, a amizade, "foi progressivamente desaparecendo do espaço público, deslocandose cada vez mais para a esfera privada e doméstica, sendo posteriormente integrada à família nuclear". Esse processo de desagregação da vida pública viria desde o século XVIII e se estende até a atualidade, no momento em que a hegemonia da família 
nuclear se impõe a todas as formas de socialização e sociabilidade, promovendo o esvaziamento de espaço público e acabando com as sociabilidades públicas da própria modernidade.

A imposição das "tiranias da intimidade", ${ }^{4}$ que ferem a cidade como mundo compartilhado, leva a uma derradeira destruição da experiência política da cidade, como dimensão da vida pública, como experiência da publicização da vida, transformando a percepção do agir político numa questão de governo, num tema do aparato do Estado, segundo Ortega. Para ele,

O fim do mundo compartilhado, do espaço dos assuntos humanos, aparece no momento em que ele é visto sob um aspecto particular e não na sua multiplicidade. Sua ênfase na pluralidade, no agonismo, na teatralidade e na performatividade, lhe impede de apresentar a esfera pública como uma unidade. Não ligando o espaço público ao Estado, não existe nenhum local privilegiado para a ação política, isto é, existem múltiplos espaços públicos que podem ser criados e redefinidos constantemente, sem precisar de suporte institucional, sempre que os indivíduos se liguem através do discurso e da ação: agir é começar, experimentar, criar algo novo, o espaço público como o espaço entre os homens pode surgir em qualquer lugar, não existindo um locus privilegiado. (Ortega, 2000, p. 22-23).

A perda das redes de sociabilidade e convivialidade, portanto, leva a que a cidade contemporânea se converta no pasto de formas de subjetivação que abolem o outro - e, portanto, a vida pública - e só reconhecem o mesmo, limitando a experiência e o acontecimento à vida intima. Toda "lógica da identidade", para Ortega estaria dominada por uma violência que anula a diferença, a singularidade, a particularidade e reduz o outro ao mesmo. Para o autor, é preciso, pois, desconstruir essas formas de subjetivação que impedem que a identidade seja uma abertura para a alteridade. Ao desconstruirmos as formas pelas quais excluímos e suprimimos a singularidade estamos nos abrindo para o outro e renovando os vínculos que estruturam o convívio urbano, fazendo da amizade um 
fator decisivo na recuperação da esfera pública, desde que ela supere a familialização e se inscreva na cidade como uma "política".

Quem também levanta esta questão é Hannah Arendt (1994), ao tratar da oposição entre poder e violência. O poder, segundo ela, seria construído através da capacidade de agir coletivamente, respeitando pactuações prévias entre todos os envolvidos naquela ação. Quando essa capacidade de realizar acordos coletivos se desintegra, o poder sai de cena e entra a violência. A presença da violência resultaria, assim, da ausência de poder. Rebatendo essa questão no espaço urbano, poderíamos concluir que, quando se afirma a identidade de cada um - ou de cada pequeno grupo que compõe a vida urbana, isso conduz à perda da capacidade de ver o outro; nesse sentido, a cidade, como espaço público resultante de acordos coletivos, passa a dar lugar à cidadela, onde uma ordem desprovida de poder passa a ser buscada por meio da imposição da violência.

A possibilidade de escapar desta imposição cerceadora da ordem, passaria, ainda segundo Arendt (apud Ortega, 2000, p. 30), pela construção de novas formas de amor mundi, formas de relacionamento voltadas para o mundo, para o espaço público, tais como a amizade, a cortesia, a solidariedade, a hospitalidade, o respeito.

A imposição de um imaginário onde a cidade não cumpre mais o papel de doadora de sentidos para a vida social está levando ao seu desencantamento como lugar das práticas da cidadania, cujo desdobramento é o empobrecimento do imaginário urbano que passa a reduzir a cidade a uma topografia, lugar de caça de "oportunidades" de conquista de mais-valias narcísicas, seja de ordem material, seja de ordem simbólica.

Transcender essa percepção da cidade como espaço unidimensional, apenas aberto às estrepolias do capital e aos interesses narcísicos, é reconhecer que a urbe pode ser, sobretudo, 
lugar de acolhimento das representações cidadãs, que se abrem para desejos, afetos e utopias (Silva, 2001). Recuperar a dimensão política da experiência do convívio urbano passaria, pois, pela disputa entre imaginários, pela quebra da hegemonia dos discursos que pregam a cidadela e pela tentativa de atualização de pactos urbanos, que sejam capazes de prover à cidade uma nova identidade, forjada na recuperação do diálogo urbano.

Assim, ao clamor de mais ordem e mais segurança, à demanda que a cidade deva se proteger como uma cidadela, talvez se possa opor a idéia de recivilização, reencantamento e de reconstrução (Portella, 1995, 110) da cidade e de uma urbanidade que desfalece. A cada aposta de aumento do contingente policial e endurecimento das penas opor-se-ia a idéia de aumento das taxas de sociabilidade e de civilidade. A mais ordem, propõe-se mais solidariedade.

Se, quando se fala de cidade, de convívio humano, é de solidariedade que se está falando, talvez possamos fazer uma espécie de genealogia do ser/estar na cidade, ou seja, uma genealogia da sociabilidade e da suportabilidade em relação ao outro, para melhor entender as saídas possíveis diante do clamor de mais ordem para a cidade. Trata-se, pois, de perscrutar em qual momento é feita uma escolha entre a cidade ou a cidadela como alternativas futuras da nossa civilização urbana.

\section{Cidades de letras}

A literatura é, talvez, um dos lugares onde melhor esse processo pode ser observado, justamente porque, ali, diferentes visões da cidade se manifestam, na medida em que o autor faz dela a cena da sua narrativa, o palco de seus personagens e, muito mais do que isso, faz da cidade o sujeito do seu enredo, dando-lhe mesmo o estatuto de personagem. Nesse sentido, o autor é levado a significar a cidade insuflando-lhe uma alma, dando-lhe vida. $\mathrm{Na}$ 
tentativa de construir sua "cidade de papel", qual um arquiteto das letras, o escritor acaba por formular sua percepção do que seja a cidade. Alguns autores, nessa operação de constituição de uma verossimilhança com o real, mais na tentativa de dar um certo "sentido" à cidade do que de reproduzir sua mineralidade, deixaramnos contundentes imagens do que deve, do que pode ser a cidade em todas as suas potencialidades como geradora do drama urbano. Por trabalhar no cerne da existência humana na cidade e transcender em muito as descrições físicas do que esta seja, o literato - e também os cineastas, os pintores, os músicos, etc... - de alguma maneira, abre-nos as portas do drama urbano, possibilitando-nos aferir todas as gradações de valores que nosso imaginário pode atribuir à cidade. Um bom exemplo disso talvez seja a Babilônia, descrita na Bíblia, que, traduzindo muito mais que um emaranhado de casas e palácios, sugere-nos a emblemática imagem da cidade como lugar da confusão. As Cidades Invisiveis, de Ítalo Calvino, nesse sentido, não são menos fascinantes: uma só cidade, Veneza, se transmuta em dezenas de outras para dar significado ao que Marco Pólo quer contar sobre as cidades do império de Kublai Khan. Para dar sentido ao império do grande Khan, Marco Pólo, justamente, escolheu as cidades, que, cada qual com sua alma, impregnam de sentido a vida dos homens sob o império. Sendo assim, essas cidades são capazes de exprimir "a tensão entre racionalidade geométrica e emaranhado das existências humanas" (cf. Gomes, 1994).

Optamos aqui, portanto, em seguir o caminho apontado por Pólo, ao modular a vida dos habitantes do império pela observação de suas cidades, traduzindo, nas suas diversas imagens urbanas, o império de Khan, a vida dos homens nesse império e os sentidos que as constituem. Aqui, as cidades - tal como as "cidades invisíveis" que compõe a Veneza descrita por Pólo - também serão inferidas através do discurso que se faz a respeito delas, e, através deste, proceder-se-á à tentativa de mapear o seu significado em diferentes conjunturas históricas. 
A lembrar aqui o personagem mitológico Teseu, selecionamos, portanto, um fio que vai desempenhar o papel de guia neste labirinto que se compõe de múltiplas opções de direções. Para detectar qual fio seguir - dentre os muitos possíveis que nos permitiriam ler este labirinto composto pelas cidades e a sua sociabilidade-, escolhemos como nossa Ariadne a produção literária.

\section{A literatura e o insuportável do convívio urbano}

A obra de arte, diz Robert Stevenson em carta a Henry James, "existe não por suas semelhanças com a vida [...], mas por sua incomensurável diferença dela, diferença deliberada e significativa" (apud Comolli,1995). É nessa diferença que o autor pode impregnar a cidade de sentidos, fazendo com que estes repercutam e traduzam de alguma maneira os limites do universo humano dos personagens.

Tomemos como caso exemplar o conto Feliz aniversário, de Clarice Lispector. Trata-se de um conto em que a autora parece desinteressada de qualquer reflexão sobre a cidade, no caso, o Rio de Janeiro dos anos 60. Em nenhum momento da narrativa esta cidade é mencionada. A referência ao Rio comparece apenas na nomeação dos bairros aos quais pertence cada um dos membros de uma família que se reúne para comemorar o aniversário de 89 anos da mãe. Toda a intriga da história está, justamente, calcada nos conflitos entre os irmãos que moram na zona sul - considerada a área nobre da cidade, e aqueles que moram nos subúrbios - no caso do Rio, região considerada atrasada e apegada a valores tradicionais. Clarice debruça-se sobre o abismo da ruptura da família, o que, por seu turno, remete-nos a pensar sobre o conflito de repertórios que a cidade estava conferindo a seus filhos no sentido da elaboração de formas de convivência que começavam a deixar de lado as práticas de um estilo de vida no qual certa experiência "comunitária" ainda se fazia presente, mas já incorporando novos sentidos do viver urbano, 
que apontavam para um certo individualismo. Este individualismo nascente viria a impregnar a vida urbana de sentidos completamente diversos. Ao tematizar a ruptura da tradição familiar, Clarice nos arrasta para a própria ruptura de significados da vivência urbana que o Rio experimentou e, a partir dos quais, a cidade abriu caminho para que um novo padrão de sociabilidade se impusesse. Nesse sentido, o fato da festa mencionada ocorrer no bairro de Copacabana, seria sintomático:

Ali está a ser engendrada uma nova idéia do que seja o "viver junto": a transição das grandes famílias que residiam em grandes casas no subúrbio para a família reduzidamente nuclear que passará a morar nos apartamentos diminutos. O panorama das relações sociais também se transforma, no momento em que os laços abrangentes construídos entre as grandes famílias e seus vizinhos se transmutam nesta paisagem multifacetada dos pequenos apartamentos, que já trazem embutida na denominação a sua principal característica: manter a todos separados. (Kuster, 2007).

O conto abordado aponta precisamente para o momento dessa transição, no qual Clarice parece antever questões que serão tratadas mais tarde por Rubem Fonseca - este sim, um autor que construiu o cerne de sua obra sobre a insuportabilidade de se viver em conjunto, e sobre o qual vamos nos deter mais demoradamente.

Fonseca tem experimentado em seus contos mostrar o endurecimento da cidade causado pela perda da comunicabilidade entre os seres urbanos e o impacto disso na estruturação de novas formas de subjetividade. Neste autor, a perda da comunhão entre os homens e, conseqüentemente, entre estes homens e a cidade, condena seus personagens à solidão, ao isolamento, ao individualismo e, muitas vezes, à violência, senão à barbárie. Nesse sentido, é interessante fazer uma espécie de genealogia da sociabilidade urbana a partir de sua obra, cujo conjunto pode nos dizer algo sobre como a cidade foi pensada em diferentes momentos, desde os anos 60 até a atualidade, e como estas diferentes percepções da cidade se inscreveram no imaginário de seus personagens. 
A partir de seu segundo livro, A coleira do cão, escrito em 1965, divisamos um universo onde os personagens, encoleirados por uma cidade que se concentra no âmbito da família, ainda não se arriscaram em conquistar o mundo. Apesar da dicção reconhecidamente urbana dos contos, nota-se que o narrador ainda está amarrado a esse universo familiar, que não lhe permite galgar o mundo, lançar-se no sorvedouro da vida urbana, em sua mais completa mundanidade. Bem que o narrador tenta alçar vôo do mundo conhecido e deixar-se mergulhar no abismo do inaudito da cidade. Mas não consegue. Madona é o conto chave que nos permite observar o narrador ganhar força para escalar o topo do mundo: a cidade. $\mathrm{O}$ conto trata da história de um típico garotão de classe média carioca da zona sul, que, em função da viagem dos pais no fim de semana, tem o apartamento livre só para si, o que o leva a devaneios eróticos. Com o propósito definido de "descolar uma gata" para rechear sua cama vazia, vai à luta - quer dizer, à rua - tentar se enturmar, com uma idéia na cabeça: "o lugar que tem mais mulher no mundo é o Rio de Janeiro" (Fonseca, 1994, p. 173). É assim que o personagem começa o périplo da paquera, que transita pela praia, pelo bar, pela festinha, e pela roda de amigos, sem que nenhuma situação redunde em qualquer beneficio que preencha seus sonhos eróticos: "Fui andando, olhando o chão, com vontade que uma moça bonita e inteligente e sensivel, dessas que moram em grandes palacetes, me visse, sentindo pena de mim" (p. 181-182).

Durante dois dias o personagem dá curso aos seus devaneios sem sucesso:

$\mathrm{Eu}$, cujos planos emergiram todos do fundo da minha cabeça; confuso: uma mulher, uma mulher, que fosse sábia, forte, tivesse calor e energia, que espremesse de dentro de mim o berne frio que ocupava um espaço em minha vida [...] me afagasse, me cansasse, me deixasse arriado e acima de tudo fosse enorme, absoluta, envolvente como a terra que cobre a sepultura. (Fonseca, 1994, p. 190). 
Ao chegar em casa, fracassado de sua caça, como último recurso, se depara com uma empregada que trabalha no seu prédio e é com ela mesmo que ele vai extravasar sua frustração. É com ela - não a "gatinha" que buscava ganhar e levar para o apartamento vazio, mas a moça que sempre esteve ali - que a relação irá acontecer nas escadas do edifício, e, afinal, a sua busca inicial por sexo se concretiza. Poderíamos dizer que ela simboliza a sua inserção nos mistérios da cidade, e lhe mostra que esses mistérios são ainda mais densos do que ele havia imaginado, à medida que o contato com eles enche-o de incerteza em relação ao próprio estar no mundo.

O personagem atinge, enfim, o seu objetivo. Entrega-se a uma relação sexual. Entrega-se ao mundo. Não completamente, porém. No momento de maior emoção, "nesse instante de apogeu sua boca procurou a minha, mas eu virei o rosto: como se aquilo fosse me doer? me perder? - também, mas principalmente como se fosse me roubar" (p. 191). O personagem não sabe bem porque recusou o beijo da moça, mas pressente que algo se transformaria a partir dali, infere que está no limiar de uma mudança.

Ato seguinte, adentra o apartamento e, sozinho na sua frustrada cama vazia, reflete: "o ruim do mundo eu ainda não tinha visto, mas faltava pouco, muito pouco para que isso acontecesse" (p. 191).

Com esse desfecho Fonseca, anuncia que seu próximo passo seria mais ousado: pôr seus personagens no "ruim do mundo" experimentando a vida da rua, como de fato vai acontecer com o policial do conto $A$ coleira do cão, que experimenta o crime e a morte diariamente no exercício da profissão, e principalmente no livro seguinte: Lúcia McCartney. Mas enquanto reúnem energias para ganhar o espaço público da cidade, os personagens de Fonseca ruminam no quarto, como é o caso de Madona. Ruminando na casa da família, acumulam energia para se lançar no mundo da impessoalidade absoluta da cidade. Essa transição privado/público, onde um se contamina do outro, de certa forma havia sido anunciada 
pelo autor já no início do livro, através da epígrafe com a qual Fonseca abriu a obra e que lhe deu o título: "Já quebrei meus grilhões, dirás talvez. Também o cão, com grande esforço, arranca-se da cadeia e foge. Mas, preso à coleira, vai arrastando um bom pedaço da corrente" (Pérsio apud Fonseca, 1994). Os personagens deste livro, tal como o protagonista de Madona, já buscam a vida no espaço público, porém, tal como o cão que arrasta um pedaço da corrente, carregam ainda certo travo de sua vida privada, familiar.

Em Lúcia McCartney, Fonseca (1978), também como uma pista para o que iremos encontrar, abre com uma citação do último livro do Novo Testamento: o Apocalipse, que ele mesmo nos informa ser uma "palavra grega que significa revelação". O que o autor deixa de nos informar é que o livro do Apocalipse traz revelações que fazem prognósticos terríveis sobre os destinos da humanidade. E Fonseca, que revelações nos trará com seu livro?

Os contos que compõem esta obra são, de uma forma ou outra, retratos de personagens que avançam em relação àqueles do livro anterior. Em Lúcia McCartney eles já ganham a cidade, ou a cidade os alcança em sua privacidade, para o bem ou para o mal. Mostremos isso em dois curtíssimos contos do livro: Corrente e $O s$ inocentes.

No primeiro deles, o título não se refere àquela corrente mencionada anteriormente, que, agarrada à coleira, vai sendo arrastada pelo cachorro. Essa corrente é de outra natureza. Menos sólida - mas não por isso menos densa -, trata-se de uma corrente de papel, composta por cartas que prometem benesses a quem a mantém girando e ameaçam com desgraças os que a rompem. O personagem do conto, de quem não temos nenhuma informação a não ser que a corrente lhe chega "após meses de sofrimento e solidão" (Fonseca, 1978, p. 133), recebe uma dessas cartas pelo correio. O mundo exterior, a cidade, a sociedade, o alcançam em seu mundo privado, 
mostrando que - a despeito de sua solidão - algo do âmbito público ainda o pode atingir. Nesse sentido, é simbólica a escolha do autor pelas cartas e pelo termo pelo qual estas são denominadas, mostrando que, por maior que possa ser o isolamento pessoal, algo sempre nos 'acorrenta' ao mundo, mesmo que essa corrente seja composta de simples e frágil papel. As cartas lhe chegam, portanto, forçando-o a tomar uma posição: aceitar o convite e participar deste coletivo simbolizado pela corrente que lhe cobra uma inserção no social, ou ignorá-las, continuando mergulhado em seu âmbito particular - e pagar o preço de tal atitude.

Vemos então, o grande problema do personagem: ele não possui amigos em lugares distantes a quem enviar as vinte e quatro cópias exigidas pela corrente. Não tem, sequer, amigos próximos aos quais mandá-las. Por mera falta de oportunidade, não pode se unir ao social que o convida à inserção. $\mathrm{O}$ final do conto vai encontrálo na cama, dentro da casa fechada, aguardando o que poderá lhe acontecer, que preço irá pagar por não poder participar da vida pública. O personagem de Corrente sabe que pagará um preço pela sua falta de possibilidade de inserir-se no coletivo. Espera resignado a cobrança que virá.

Já em outro conto do mesmo livro, Os inocentes, vamos direto ao extremo oposto deste processo de desinscrição social, ou seja: seus personagens, à semelhança do rapaz do conto Madona, vão para o mundo. Mas, ao contrário deste, que ainda não travara contato com o ruim do mundo, aqueles já estão expostos a ele. Escolhem, porém, ignorá-lo.

O conto inicia-se com a descrição de um corpo feminino que veio dar à praia: "O mar tem jogado na praia pingüim, tartaruga gigante, cação, cachalote. Hoje: mulher nua” (Fonseca, 1978, p. 169). O autor não perde tempo com preâmbulos, essas são as primeiras frases do texto, que prossegue na descrição minuciosa do 
corpo e de seu estado já deteriorado. O confronto com a morte não parece chocar especialmente os que a cercam: "banhistas instalam barracas longe da coisa morta, logo envolvida por enorme circulo de areia, indiferença" (idem). A "areia/indiferença" que preenche o espaço entre o corpo e os banhistas já é sinal de que algo modificouse na convivência coletiva. Os participantes da vida das cidades, tal como apontado por Simmel (1973) desde o início do século XX, precisam se proteger das emoções extremas, não podem mais reagir com igual intensidade a tudo que os envolve. Assim, desenvolve-se o que esse sociólogo denominou de "atitude blasé", ou seja, uma certa "capa" de indiferença, com a qual o participante da vida urbana se envolve, e que lhe permite continuar o jogo diário de interação com os diversos componentes da cidade. Segundo ele,

Nesse fenômeno, os nervos encontram na recusa a reagir a seus estímulos a última possibilidade de acomodar-se ao conteúdo e à forma da vida metropolitana. A autopreservação de certas personalidades é comprada ao preço da desvalorização de todo o mundo objetivo, uma desvalorização que, no final, arrasta inevitavelmente a personalidade da própria pessoa para uma sensação de igual inutilidade. (Simmel, 1973, p. 17).

Assim que, confrontados com um corpo nu que vem dar à praia, os que chegam à areia não fazem mais do que instalar suas barracas longe da "coisa morta". Curiosa denominação, que destaca o fato de que aquele corpo não é mais visto como tendo sido uma pessoa. Caso fosse, obrigaria a uma reação mais forte daqueles banhistas. O mundo lhes chega, portanto, no paradoxo entre a manhã de sol e o dia de divertimento que se anuncia na praia, e o corpo que lhes lembra o drama da finitude da vida. Ganhar a cidade, lançarse ao mundo, implica em entrar em contato com suas múltiplas faces, o autor parece querer dizer. Os banhistas de Fonseca têm que fazer uma escolha: com qual parte do mundo vão ficar. E fazem. Ignoram o corpo e continuam em suas rotinas. Porém, como havia nos alertado Simmel, a desvalorização que se confere a outrem, 
"arrasta inevitavelmente a personalidade da própria pessoa para uma sensação de igual inutilidade". Os personagens que se derramam por outros contos do escritor vão se tornar mais e mais impermeáveis ao outro, mais e mais endurecidos em relação ao mundo, como veremos nos livros seguintes.

Por fim, corpo retirado, resta o "espaço vazio cercado pelo colorido das barracas, lenços, biquinis, chapéus, toalhas, por todos os lados. Chega a familia: 'Olha, parece que reservaram um lugar para nós" (Fonseca, 1978, p. 169). O rápido preenchimento do espaço vazio colabora para o rápido esquecimento do episódio. Esquecimento esse que, inferimos, é desejado por todos. A família que chega, após o fim do episódio, traz consigo uma certa "inocência" da cidade, não tocada ainda pelo "mal do mundo" que estaria, aqui, simbolizado pelo corpo da morta. Estes "inocentes" seriam aqueles aos quais se refere o título do conto: permanecem na ignorância do corpo que ali estava momentos antes, e, mais do que isso, conservam-se, ainda, "desarmados" frente a esse mal do mundo que se anuncia.

No livro seguinte, Feliz ano novo, já temos os personagens encouraçados para a vivência coletiva. Ali, eles já estão armados, seja essa arma metaforizada em um carro ou concretizada em uma arma real. Fonseca inicia este livro com uma expressão retirada das Epistolas, de Horácio: "Singula de nobis anni praedantur euntes"5 (Fonseca, 1989). Perante a contundência da frase, percebemos que aqui já não mais haverá personagens inocentes. A "inocência" dos citadinos - os seus "bens" - lhes foram arrebatados "um a um".

São vários os contos do livro que nos mostram sintomas desse mundo no qual o convívio está se tornando insuportável. Passeio noturno é um conto que se divide em duas partes: na primeira parte, encontramos um personagem: um executivo. Assoberbado pelos seus afazeres no mundo dos negócios, descobriu uma forma inusitada 
de relaxar: depois do jantar em família, pega seu automóvel de pára-choques salientes e "reforço especial duplo de aço cromado" (Fonseca, 1989, p. 62) e sai à rua. Qual caçador experiente, espreita os transeuntes de dentro de seu carro, até que divisa sua caça. Segue a pessoa, aguardando a oportunidade perfeita, quando, sem hesitação, acelera o carro e a atropela. Depois de se certificar da morte da vítima, retorna à sua casa, mais calmo. Inspeciona seu automóvel na garagem, orgulhoso da ausência de danos, entra e vai dormir. Despede-se da família, antevendo: “amanhã vou ter um dia terrivel na companhia" (p. 63).

$\mathrm{Na}$ segunda parte do mesmo conto, vamos encontrar novamente o mesmo personagem. Sua prática de relaxamento continua a mesma. Agora, porém, ele se estende um pouco mais: em substituição à escolha impessoal feita do interior do automóvel, ele passa a dedicar algum tempo conhecendo sua futura vítima. Sai para jantar com a moça, conversa um pouco. Ao final, o mesmo desfecho: o executivo, encapsulado pela poderosa carroceria de seu jaguar, a atropela e mata. Retorna para casa e se despede da família proferindo exatamente a mesma frase da primeira parte do conto.

Há aí, claramente colocada, uma transição. O personagem que antes se resguardava dentro do automóvel na sua prática bárbara, passa a se expor um pouco mais ao mundo. Fonseca narra a saída do personagem de seu carro - o seu 'mundo' - atraído que foi pela vítima em potencial. Vemos o encontro com a moça, a saída para jantar e a conversa que acontece no transcorrer deste, que não tem um desenrolar satisfatório. Apesar da aparente inexpressividade do encontro, o executivo se consola, pensando: "Aquela situação, eu e ela dentro do restaurante, me aborrecia. Depois ia ser bom" (p. 70). Podemos, nestas descrições das etapas do encontro, ver enunciada uma erótica. Antevemos, através dos olhos do personagem principal, que um prazer está por vir, e este, inferimos, será de ordem sexual. Tal antevisão, todavia, não se concretiza. O gozo que acontece, tem, 
sim, o corpo do outro como objeto. Não para uma erótica, porém, e sim para a violência. O prazer que - imaginava-se - seria sexual, revela-se mortal.

O executivo, ao deixar a moça em casa, age como sempre: atropela-a, certificando-se de sua morte, já que "não podia correr o risco de deixá-la viva. Ela sabia muita coisa a meu respeito, era a única pessoa que havia visto o meu rosto, entre todas as coisas. E conhecia também o meu carro" (p. 71). Embora o final seja semelhante nos dois contos, algo se transforma no personagem principal, assim como se transforma na escrita de Fonseca. A ida para o mundo já aconteceu, não tem mais volta. O "ruim do mundo" já está na cidade do autor: a morte do outro se torna fonte de prazer.

Mas, sem dúvida, o conto que dá título ao livro, Feliz ano novo, é o carro chefe desta nova fase. Retrato da violência crescente nas grandes cidades, o conto aborda o encontro entre dois universos sociais absolutamente incomunicáveis: de um lado o grupo composto pelos três protagonistas, Pereba, Zequinha, e o narrador do conto, do qual não sabemos o nome; e do outro, os "bacanas", que comemoram a virada de ano em uma residência em São Conrado. O Rio de Janeiro deste momento está em um processo crescente de esgarçamento da sociabilidade. Em análise à obra de Fonseca, Vera Foulain Figueiredo (2003, p. 29) resume:

A ficção de Fonseca alimenta-se, assim, dos impasses vividos pelo homem contemporâneo, espelha o paradoxo de um tempo que se nutre da desconstrução das utopias que sustentavam os sonhos de transformação do mundo. O relativismo axiológico, entretanto, é, de certa forma, remédio e veneno: levado às últimas conseqüências para desestabilizar as certezas que serviram aos ideais totalitários, pode gerar em contrapartida, a indiferença que abre espaço para o consenso conformista contra o qual o texto do autor se volta.

É nesse fio da navalha, portanto, que o conto caminha. O seu desenrolar é previsível: a frustração com a noite de festa passada 
em meio à pobreza, o carro roubado, a volta pela cidade à procura de uma oportunidade de ganho, o assalto durante a festa, a volta para o "cafofo"”. O que talvez surpreenda e nos choque, não são os acontecimentos violentos narrados no conto, mas a barbárie que esta violência exprime.

Seja em fatos maiores ou menores, o autor dota seus personagens de atitudes que ultrapassam a simples violência, indo em direção a formas de agir que revelam que há algo profundamente perturbador nesse mundo no qual a sua escrita parece se mover com tanta destreza:

Tinha um anel que não saía. Com nojo, molhei de saliva o dedo da velha, mas mesmo assim o anel não saía. Fiquei puto e dei uma dentada, arrancando o dedo dela. Enfiei tudo dentro de uma fronha. $\mathrm{O}$ quarto da gordinha tinha as paredes forradas de couro. A banheira era um buraco quadrado grande de mármore branco, enfiado no chão. A parede toda de espelhos. Tudo perfumado. Voltei para o quarto, empurrei a gordinha para o chão, arrumei a colcha de cetim da cama com cuidado, ela ficou lisinha, brilhando. Tirei as calças e caguei em cima da colcha. Foi um alívio, muito legal. (Fonseca, 1989, p. 18)

Em apenas um parágrafo, temos um ato de extrema violência física - um dedo arrancado - e outro de extrema violência simbólica - a profanação da pureza da cama e sua colcha de cetim. Ao equiparar esses dois atos, o autor está tratando de algo que vai além dos simples gestos que traduzem a barbárie, indo em direção a algo mais amplo: um panorama onde os componentes da vida urbana não se reconhecem mais como semelhantes. Isso faz com que aquele "mal do mundo" anunciado pelo escritor anteriormente torne-se mais e mais presente, ocupando os interstícios de um mundo que se torna mais e mais desencantado. 


\section{A arte de viver nas cidades}

Podemos, a partir do agravamento da intolerância e escassez de convivialidade mostrado pelo autor, achar que quanto mais avançamos na análise de seus livros, mais o escritor nos acena com um mundo em que o "mal" cresce a ponto de não deixar espaço para mais nenhuma possibilidade. Porém, aquilo que em Rubem Fonseca parece sem saída, no que diz respeito ao convívio na cidade, pode ser lido, na verdade, como uma enorme esperança de que na urbe todos os afetos possam ser vividos e experimentados. Fonseca leva às últimas conseqüências a experiência da vida social, o que significa dar à cidade o estatuto de pólis, lugar da philia, ou seja, lugar do encontro, disponibilidade para a sociabilidade, o que não supõe, evidentemente, ausência de conflito - e que conflitos - na conquista de uma "humanidade".

Se passarmos dos personagens transgressores de Feliz Ano Novo (1975) para o flâneur do conto $A$ arte de andar nas ruas do Rio de Janeiro (1992), veremos como Rubem Fonseca retraça as possibilidades dos destinos na urbe. Trata-se de um homem que perambula pela cidade e que tem como meta escrever um livro sobre a arte de andar nas ruas. Não é o caso, absolutamente, de escrever um guia turístico, nem um manual de urbanismo, mas sim de produzir uma narrativa amorosa na qual o personagem quer restabelecer para o leitor a possibilidade de comunhão com a cidade. Nesse sentido, o conto nos revela um homem que flana pela cidade, poroso a todo e qualquer acontecimento. Fonseca faz dessa disponibilidade de seu personagem uma metáfora para o que deveria ser o espírito da urbanidade. Este homem tem por objetivo resolver os problemas de uma cidade não compartilhada e perversa e está imbuído de uma espécie de missão urbano-ética, que é a de "ensinar" a vida na cidade - ou seja, a convivialidade - aos leitores e mesmo àqueles que nem sabem ler. Observando esse personagem podemos concluir que Fonseca quer atribuir à cidade o lugar de 
articuladora dos destinos humanos, ou seja, a cidade "propõe", mas é o urbanóide quem dispõe: "Augusto quer encontrar uma arte e uma filosofia peripatéticas ${ }^{6}$ que o ajudem a estabelecer uma melhor comunhão com a cidade". Andando pelo centro histórico de uma cidade labiríntica, Augusto procura estabelecer uma religação com esta a partir do centro, que é sempre o lugar de origem, lugar de história de qualquer cidade. Augusto "quer fazer-se um com a cidade, comungá-la. Quer restaurar o diálogo com o outro nesse espaço marcado pela diferença que gera, porém, a indiferença..." (Gomes, 1994, p. 151).

É significativo observar que quando Rubem Fonseca põe seu personagem a perambular pelas ruas do Rio, ele se deixa atravessar pela aura dos filósofos da pólis grega que exaltavam o papel pedagógico da vida pública, entendida como lugar da imortalidade, onde cada cidadão deveria se constituir como pertencente à cidade. Pondo seu personagem a morar no centro da cidade por onde este circula, Fonseca sugere-nos que a centralidade de uma cidade é o lugar a partir do qual esta doa sentido à vida de seus cidadãos. É a partir dessa centralidade, portanto, que uma identidade é possível. Não é por beletrismo, então, que Fonseca nos fala de solvitur ambulando, ou seja, resolver os problemas passeando, como Sócrates fazia com seus discípulos. $\mathrm{O}$ escritor evoca a pólis, no mesmo diapasão com que menciona a tentativa do personagem desenvolver uma filosofia peripatética, de forma que esta pólis seja, ao menos, um ruído ao longe a ajudar a encorpar a voz da cidade.

A cidade real, no entanto, independente da pólis de Fonseca, continua a vomitar seus seres excremenciais, a pôr em cena todo tipo de barbárie e a escandalizar com seus viventes, sem limite nenhum, só o do seu próprio gozo e o de seus interesses individuais. A cidade real, aquela que sai nos jornais e nos chega de manhãzinha com o pão e o café, que hão de nos ajudar a atravessar o doloroso dia, insiste numa tragédia urbana. ${ }^{7}$ 
A resposta de Fonseca a esse estado de coisas de nossa urbanidade veio com o livro Pequenas Criaturas, que, segundo Vera Follain Figueiredo (2003, p. 163), é um diálogo irônico com a tragédia grega. Para um autor que já mostrou pensar que os problemas se resolvem andando (solvitur ambulando) - ou seja, para quem acha que estar no espaço público é a única maneira de equacionar os problemas, ou, melhor ainda, para quem a cidade como lugar do outro, do diferente, é a possibilidade limite de tematizar a experiência humana - evocar a tragédia grega para falar do cotidiano das pequenas criaturas nas grandes cidades é repensar a cidade não mais pelo ângulo da "banalidade do mal", mas pela crise contemporânea de valores. Assim, se as ações dos grandes heróis, deuses e semi-deuses gregos repercutem no mundo e nos propõem as grandes questões da filosofia que tematizam a existência do ser, as escolhas das pequenas criaturas urbanas não repercutem no mundo dada a sua mesquinhez. Segundo Vera Follain Figueiredo (2003, p. 166), "os personagens do livro revivem, assim, num diapasão amesquinhado, os grandes dilemas trágicos... Rubem Fonseca traz, assim, as grandes indagações do homem que a tragédia grega, com seus personagens heróicos, de origem nobre, dramatizou, para o universo do homem comum" e faz os seus personagens reviverem as grandes questões que a tragédia grega ressaltou, tendo que "criar seus próprios deuses, mergulhado[s] na solidão a que a ausência de valores compartilhados coletivamente o [s] condena". A tragédia, conclui Vera Follain Figueiredo, "realiza-se, hoje, num diapasão subjetivo e nostálgico, em meio a uma sociedade em que o sentido da ordem se perde...".

O grande feito, diante da nossa realidade, perante o "ruim do mundo" que o autor já havia anunciado décadas antes e que, finalmente, se impõe como força constituidora do drama citadino contemporâneo, é, apenas e tão-somente, sobreviver.... na cidade. Os que o conseguem, solitariamente, em meio a essa sociedade 
que perdeu o sentido de ordem, poderiam, aos olhos do autor, ser equiparados aos grandes heróis clássicos.

Saímos dos braços da literatura e dos personagens de Fonseca e nos debruçamos de novo sobre o abismo de nossa realidade primeira: nossas reflexões sobre o papel da ordem e, mais do que isso, que tipo de ordem desejamos para a vida urbana?

O café esfriou, a notícia do dia já não é mais novidade e o jornal foi para a lata do lixo. Em face das notícias que nos despertam essas reflexões, ainda não temos a resposta que nos permitiria acordar e viver cotidianamente neste "ruim do mundo". Apenas ficamos nos perguntando: páginas policiais ou páginas literárias? Em qual delas deveríamos buscar o sentido da ordem necessária para as nossas cidades?

\section{Notas}

1 Nesse sentido ver os ensaios de Olgária Matos (2006), “A identidade: o estrangeiro em nós", "Ethos e amizade: a morada do homem" e "Babel e Pentecostes: heterofilia e hospitalidade".

2 É sempre interessante lembrar que 'Civitas' (cidade) deriva de 'Civis' (civil), que diz respeito ao cidadão, àquilo que transcende a vida particular. Deriva daí, também, o termo 'Civilitas' (civilidade), que nos remete para a noção de respeito mútuo, cortesia, urbanidade. Cidade, civil e civilidade amarram-se, então, para nos dizer algo da cidade relativo à experiência da vida pública.

3 Para análise do processo de despolitização da vida pública e constituição de uma "esfera íntima" que se oporia a uma "esfera pública", ver: Ortega (2002).

4 Para uma analise histórica da "destruição" da vida pública, ver Sennett (1988). 
5 “Os anos que passam nos arrebatam os nossos bens um a um" [tradução dos autores].

6 Palavra que deriva da filosofia grega, e que significa o ato de ensinar passeando.

7 Veja-se a repercussão do filme Tropa de Elite e o impacto que ele alcançou em nível nacional.

Order. City. Literature: characters on the edge of the "world's worst"

\begin{abstract}
The great cities are sick. Its indications: the sociability in addition and the routine irruption of the violence. Ahead of this, a outcry for order echoes in the society. At the same moment where the policy goes to the street, the writers create personages who give voice to the increasing sensation of that the city is leaving of being a reference to the constitution of the urban identities. It is from literature, in special of the writer Rubem Fonseca, that we will go to investigate the possibilities presented for the city for the human conviviality.
\end{abstract}

Keywords: city, citizenship, order, literature, Rubem Fonseca

\title{
Referências
}

ARENDT, Hannah. Sobre a violência. Rio de Janeiro: Relume Dumará, 1994.

COMOLLI, Jean L. A cidade filmada. Cadernos de Antropologia e Imagem, Rio de Janeiro, n.4, 1995.

FERREIRA, Aurélio Buarque de Hollanda. Dicionário Aurélio básico da língua portuguesa. Rio de Janeiro: Nova Fronteira, Folha de São Paulo, 1995.

FONSECA, Rubem. Os prisioneiros. Rio de Janeiro: Arte Nova, 1963. 
FONSECA, Rubem. Coleira do cão. Rio de Janeiro: Arte Nova, 1965. . Lúcia McCartney. Rio de Janeiro: Codecri, 1978. . Feliz ano novo. 2. ed. São Paulo: Companhia das letras, 1989. . O cobrador. Rio de Janeiro: Nova Fronteira, 1979. . Romance negro. São Paulo: Companhia das letras, 1992. . Contos reunidos. São Paulo: Companhia das Letras, 1994. . Histórias de amor. São Paulo: Companhia das letras, 1997. . Pequenas criaturas. São Paulo: Companhia das letras, 2002.

FIGUEREDO, Vera Follain. Os crimes do texto. Belo Horizonte: EDUFMG, 2003.

GOMES, Renato Cordeiro. Todas as cidades, a cidade. Rio de Janeiro: Rocco, 1994.

KUSTER, Eliana. Comemorar na cidade: Clarice Lispector, Rubem Fonseca e suas felicidades urbanas. Rio de Janeiro: Fotocópia, 2007.

MATOS, Olgária. Discretas esperanças: reflexões filosóficas sobre o mundo contemporâneo. São Paulo: Nova Alexandria, 2006.

ORTEGA, Francisco. Genealogias da amizade. São Paulo: Iluminuras, 2002.

. Para uma política da amizade: Arendt, Derrida, Foucault.

2. ed. Rio de Janeiro: Relume Dumará, 2000.

PORTELLA, Eduardo. Educação pela cidade. Revista Tempo Brasileiro, Rio de Janeiro, n. 120, jan. mar. 1995.

SENNETT, Richard. O declínio do homem público: as tiranias da intimidade. São Paulo: Cia. das Letras, 1988.

SILVA, Armando. Imaginários urbanos. São Paulo: Perspectiva, 2001.

SIMMEL, Georg. A metrópole e a vida mental. In: VELHO, Otávio Guilherme. O fenômeno urbano. Rio de Janeiro, 1973. 